\title{
The influence of a modified micro-environment on stress and milk production through the plasminogen-plasmin system in Murrah buffaloes during the hot-humid season
}

\author{
Nilufar Haque ${ }^{1 *}$, Mahendra Singh ${ }^{2}$, and Sheikh A. Hossain ${ }^{3}$ \\ IDepartment of Veterinary Physiology and Biochemistry, SDAU, SK Nagar, Gujarat, India \\ ${ }^{2}$ Dairy Cattle Physiology Division, National Dairy Research Institute, Karnal, Haryana, India \\ ${ }^{3}$ National Dairy Development Board, Anand, Gujarat, India
}

\begin{abstract}
HAQUE, N., M. SINGH, S. A. HOSSAIN: The influence of a modified microenvironment on stress and milk production through the plasminogen-plasmin system in Murrah buffaloes during the hot-humid season. Vet. arhiv 88, 201-213, 2018.
\end{abstract}

\section{ABSTRACT}

To determine the changes in milk yield and composition along with the plasminogen-plasmin (PG-PL) system of milk, plasma hormones and metabolites during the hot humid season, buffaloes were divided in two groups: control and treatment, where treatment group animals had the benefit of mist and fan cooling from 9:30 am to 5:00 pm for a 6 week period, while control group animals did not have this benefit. The average maximum temperature and temperature humidity index during this season was $34.33^{\circ} \mathrm{C}$ and 84.18 , respectively. Physiological responses were recorded, and milk and blood samples were collected at weekly intervals for six weeks. The treatment group animals experienced better comfort as their physiological responses, such as respiration rate, pulse rate, and skin temperatures, were significantly $(\mathrm{P}<0.05)$ reduced as compared to the controls, and this subsequently resulted in higher milk yield, by 14.56 per cent. Analysis of milk samples revealed a higher concentration of plasminogen $(8.38 v s 6.82 \mu \mathrm{g} / \mathrm{mL})$ and $\beta$-casein $(1.11$ vs $1.02 \mathrm{~g} / \mathrm{dL})$, and lower plasmin level $(0.213 v s 0.226 \mu \mathrm{g} / \mathrm{mL})$ in buffaloes in the treatment group as compared to the controls. Plasma growth hormone and glucose levels were higher, whereas, cortisol and non-esterified fatty acids levels were lower $(\mathrm{P}<0.05)$ in the treatment animals. However, exposure of buffaloes to the cooling system did not alter the composition and calcium content of milk or catecholamine levels in plasma. Hence it may be concluded that provision of a cooling system during the summer was effective to minimize environmental stress and improve milk production by manipulation of the PG-PL system in buffaloes.

Key words: Murrah buffalo; hot-humid season; mist and fan; plasminogen-plasmin; blood metabolite; heat stress

\footnotetext{
${ }^{*}$ Corresponding author:

Dr. Nilufar Haque, Assistant Professor, Department of Physiology and Biochemistry, College of Veterinary Sciences and AH, SDAU, SK Nagar, Dantiwada, Banaskantha, Gujarat -385506, India, Phone: +91 800021 2952; E-mail: haquenilufar@gmail.com
} 
N. Haque et al.: Improved milk yield by modifying the micro-environment in Murrah buffaloes

\section{Introduction}

India is home to a great biodiversity of buffalo germplasm, including the world famous Murrah buffaloes, which are renowned for high milk production potential. According to Basic Animal Husbandry \& Fisheries Statistics (BAHFS, 2014), India has about 108.7 million buffaloes which represent about 58 percent of the world buffalo population, and they contribute more than $51 \%$ of the total milk in the country. However, exposure to high ambient temperatures in buffalo evokes depression in feed intake and utilization, disturbance in water metabolism, protein, energy, mineral balance, enzymatic reactions, hormonal secretions and blood metabolites, and ultimately down regulates milk production (BURGOS et al., 2007). Experiments have shown a decrease of $0.26 \mathrm{~kg} / \mathrm{day}$ in milk yield for each increase in temperature humidity index or THI (BROWN-BRANDL et al., 2003). As a result, lactating animals develop numerous physiological mechanisms for coping with this stress. The physiological responses of these animals to environmental stress show that seasonal stress has aprofound effect on some biochemical parameters (NAZIFI et al., 1999). Such stress can result in an inability to maintain constant body temperature, affecting the animals' health and leading to lower productivity. An increase in body temperature of around $1.0^{\circ} \mathrm{C}$ may result in detectable, deleterious effects on metabolism, tissue integrity, and a significant depression in production (McDOWELL et al., 1976; SHEBAITA and EL-BANNA, 1982). An understanding of these mechanisms can lead to the development of improved techniques for enhancing livestock productivity in tropical environments.

Experimental studies in cows have revealed that the reduction in milk yield during heat stress is modulated by a negative regulatory feedback system present in the milk (SILANIKOVE et al., 2009). It includes the plasminogen activator (PA)-plasminogen (PG)-plasmin (PL) system, which acts on $\beta$ casein $(\beta-C N)$ and converts it into a fraction $\beta$ casein $\mathrm{f}(1-28)$ which then down regulates milk secretion in cows and goats. However, heat stress in dairy animals can be managed using different approaches, such as cooling and shading. Therefore, there is an urgent need for the study of the effects of changes to the external macro-environment into an acceptable micro environment for higher milk production. In addition to this, no research has been conducted to learn about the PG-PL system status in lactating buffaloes under different microclimates. Keeping the above points in view, the present research work was planned to assess the impact of a mist and fan cooling system on plasma hormones, metabolites, milk yield, the composition and plasminogen-plasmin system of buffalo milk during the hot-humid $(\mathrm{HH})$ season.

\section{Materials and methods}

Selection of animals and experimental design. The present study was conducted at the Cattle Yard of the National Dairy Research Institute (NDRI), Karnal (Haryana) which 
is situated at an altitude of 250 meters above mean sea level, at a latitude of $29^{\circ} 42^{\prime \prime} \mathrm{N}$ and longitude of 79 $54^{\prime \prime}$ 'E. The experiment was carried out for 6 weeks during the hot and humid season (August-September). Twelve lactating Murrah buffaloes in their $2^{\text {nd }}$ or $3^{\text {rd }}$ parity were selected, with an average milk yield of $6.5 \mathrm{~kg} /$ day and stage of lactation of $120 \pm 10$ days. The buffaloes were further divided equally into two groups, i.e. control and treatment groups, comprising six animals each. The animals in the treatment group were provided with a mist (1 mm single pore) and fan (48" blade size, $1400 \mathrm{rpm}$ ) cooling facility (air velocity ranged between $8-10 \mathrm{~km} / \mathrm{h}$, water displaced $20 \mathrm{lit} / \mathrm{h}$ ) under a shed, from 9:30 am to 5:00 pm, continuously during the experimental period, while the control group buffaloes were maintained without the mist and fan. All the experimental buffaloes were fed on a ration based on the KEARL (1982) feeding standard, consisting of roughage (berseem, oats, maize or jowar fodder) as per availability on the farm. The concentrate mixture consisted of de-oiled mustard cake 12 parts, ground nut cake 21 parts, maize 33 parts, wheat bran 20 parts, rice bran 11 parts, mineral mixture 2 parts and common salt 1 part, was offered individually to each buffalo at $8.30 \mathrm{am} @ 1 \mathrm{~kg}$ per $2.0 \mathrm{~kg}$ of milk production during morning and evening milking. Fresh tap drinking water was available to all the animals round the clock.

Recording of climatic variables. Microclimatic data viz., dry and wet bulb temperatures, minimum and maximum temperatures and relative humidity were recorded in the morning $(7: 30 \mathrm{am})$ and afternoon $(2: 20 \mathrm{pm})$ using a thermometer (Zeal, London, UK) weekly during the experimental period. THI was calculated using the formula JOHNSON et al., (1963) i.e., THI $=0.72(\mathrm{Tdb}+\mathrm{Twb})+40.6$; where, $\mathrm{Tdb}=$ dry bulb temperature $\left({ }^{\circ} \mathrm{C}\right), \mathrm{Twb}=$ wet bulb temperature $\left({ }^{\circ} \mathrm{C}\right)$.

Recording of physiological parameters. The rectal temperature (RT) was recorded with clinical mercury and glass thermometer. Respiration rate (RR) was recorded by the flank method and pulse rate (PR) was counted by observing the pulsation of the middle coccygeal artery at the base of the tail and the results are expressed per minute. Skin temperature (ST) at different regions (Forehead, Middorsal, Thigh) was recorded using a non-contact telethermometer (Raytek, Model Raynger ST2L, Surrey Scientific, Surrey, UK) by holding it 2-3 inches from the skin surface.

Collection and analysis of milk and blood samples. The buffaloes were hand milked during the experiment and the milk yields (MY) were recorded daily. Milk samples were collected twice a day ( 6 am and $6 \mathrm{pm})$ at weekly intervals, coinciding with the day of blood sampling, and were brought to the laboratory as soon as possible to analyze fat, protein, lactose and solids-not-fat (SNF) using a Lacto Scan- automatic milk analyzer (Mega netoo, Bulgaria). A partial sample $(2 \mathrm{~mL})$ was centrifuged at $12000 \mathrm{rpm}$ for 60 minutes at room temperature and the milk plasma was separated out and stored frozen at $-20{ }^{\circ} \mathrm{C}$ for further analysis. Blood samples were collected at 8 a.m. at weekly intervals 
N. Haque et al.: Improved milk yield by modifying the micro-environment in Murrah buffaloes

from the jugular vein in sterile heparinised vacutainer tubes (BD VacutainerTM, UK). Plasma was separated out by centrifuging at $3000 \mathrm{rpm}$ at room temperature for 25 minutes and it was stored frozen at $-20^{\circ} \mathrm{C}$ until analysis.

Milk plasma was used for estimation of milk plasminogen, plasmin and $\beta$-casein using a bovine plasminogen ELISA kit (Catalog No. EBP2211-1), a bovine plasmin ELISA kit (Catalog No. MBS755618) and a ELISA kit for $\beta$-casein in bovine milk (Catalog No. E98332BO), respectively, procured from USCN Life Science Inc, Wuhan, China. The calcium (Ca) content in the milk was estimated using an atomic absorption spectrophotometer (Model Z-5000, Polarized Zeeman AAS, Hitachi High-Technologies Corporation, Tokyo, Japan). Hormonal profiles from blood plasma samples were determined using the following ELISA kits: cortisol by a "bovine cortisol ELISA kit", growth hormone (GH) by a "bovine GH Elisa kit" (Catalog No. ERK- B1008) (Endocrine Technologies, Fircrest Street, Newark, USA), epinephrine (E) and norepinephrine (NE) by a 2- CAT ELISA Fast Track kit (Labor Diagnostika Nord GmbH \& Co. KG, Am Eichenhain, Nordhorn, Germany). Glucose was estimated in plasma samples using glucose oxidase-peroxidase (GOD-POD) kits procured from Span Diagnostics Ltd. The copper soap solvent extraction method (SHIPE et al. 1980), with slight modifications, was adopted for estimation of plasma non-esterified fatty acids (NEFA).

Statistical analysis. Data were analyzed by the general linear model procedure (SPSS version 20.0, 2011, IBM Corporation, Armonk, NY, USA) using repeated measures ANOVA with repeated measures over time and the buffalo as the experimental unit. The data generated are presented as mean with SEM. Overall differences between treatment means were considered significant when $\mathrm{P}<0.05$, unless otherwise noted, and trends are discussed at $\mathrm{P}<0.10$.

\section{Results}

The average maximum temperature and THI during the hot and humid season (August-September) was $34.33{ }^{\circ} \mathrm{C}$ and 84.18 , respectively (Table 1). Average relative humidity during the experimental period was recorded as 90.63 percent. The effect of the mist and fan cooling system on physiological parameters is shown in Table 2. There was no effect from the cooling system on RT, however, it was helpful in reducing respiration and pulse rate significantly $(\mathrm{P}<0.001)$ in the treatment group. The skin temperature was recorded to be significantly lower $(\mathrm{P}<0.05)$ with the provision of mist and fan to the treatment animals during the hot and humid season.

Milk yield was significantly $(\mathrm{P}<0.05)$ higher in the treatment group, reflecting the fact that mist and fan cooling during the summer was helpful in alleviating environmental stress, and helped in restoring milk production (Table 3), although the milk composition and calcium concentration were unaltered in the summer. However, higher concentrations 
N. Haque et al.: Improved milk yield by modifying the micro-environment in Murrah buffaloes

$(\mathrm{P}<0.05)$ of plasminogen and $\beta$-casein, by 22.9 and $8.82 \%$, respectively, and lower plasmin levels $(0.213$ vs $0.226 \mu \mathrm{g} / \mathrm{mL} ; \mathrm{P}<0.05)$ were found in the milk of buffaloes in the treatment group as compared to the control.

Table 1. Mean environmental variables during experimental period of hot-humid season

\begin{tabular}{|c|c|c|c|c|c|c|c|}
\hline \multirow{2}{*}{$\begin{array}{l}\text { Environmental } \\
\text { variables }\end{array}$} & \multicolumn{6}{|c|}{ Weeks } & \multirow{2}{*}{$\begin{array}{c}\text { Overall } \\
\text { mean } \pm \text { SE }\end{array}$} \\
\hline & $1^{\text {st }}$ & $2^{\text {nd }}$ & $3^{\text {rd }}$ & $4^{\text {th }}$ & $5^{\text {th }}$ & $6^{\text {th }}$ & \\
\hline $\begin{array}{l}\text { Maximum } \\
\text { temperature }\left({ }^{\circ} \mathrm{C}\right)\end{array}$ & 32.3 & 33.8 & 34.3 & 34.7 & 35.1 & 35.8 & $34.33 \pm 0.18$ \\
\hline $\begin{array}{l}\text { Minimum } \\
\text { temperature }\left({ }^{\circ} \mathrm{C}\right)\end{array}$ & 24.4 & 25.1 & 25.9 & 26.4 & 26.7 & 26.9 & $25.90 \pm 0.16$ \\
\hline $\begin{array}{l}\text { Relative } \\
\text { humidity (\%) }\end{array}$ & 88.3 & 91.7 & 90.3 & 90.7 & 91.3 & 91.5 & $90.63 \pm 0.78$ \\
\hline $\begin{array}{l}\text { Temperature } \\
\text { humidity index }\end{array}$ & 82.28 & 83.06 & 83.94 & 84.31 & 85.58 & 85.92 & $84.18 \pm 0.27$ \\
\hline
\end{tabular}

Table 2. Effect of mist and fan cooling system on physiological responses and skin temperatures of lactating Murrah buffaloes $(\mathrm{n}=12)$ during hot-humid season

\begin{tabular}{|c|c|c|c|c|c|c|c|c|c|c|}
\hline \multirow{2}{*}{$\begin{array}{l}\text { Physiological } \\
\text { Parameters }\end{array}$} & \multirow[b]{2}{*}{ Groups } & \multicolumn{6}{|c|}{ Week } & \multirow{2}{*}{$\begin{array}{l}\text { Overall } \\
\text { mean }\end{array}$} & \multirow[b]{2}{*}{ SEM } & \multirow{2}{*}{$\begin{array}{l}\text { Significance } \\
\text { of effect }(\mathrm{P})\end{array}$} \\
\hline & & $1^{\text {st }}$ & $2^{\text {nd }}$ & $3^{\text {rd }}$ & $4^{\text {th }}$ & $5^{\text {th }}$ & $6^{\text {th }}$ & & & \\
\hline \multirow{2}{*}{$\begin{array}{l}\text { Rectal } \\
\text { temperature } \\
\left({ }^{\circ} \mathrm{C}\right)\end{array}$} & Control & 38.39 & 38.39 & 38.39 & 38.39 & 38.39 & 38.39 & 38.00 & \multirow{2}{*}{0.048} & \multirow{2}{*}{0.154} \\
\hline & Treatment & 38.26 & 38.26 & 38.26 & 38.26 & 38.26 & 38.26 & 37.85 & & \\
\hline \multirow{2}{*}{$\begin{array}{l}\text { Respiration } \\
\text { rate/ minute }\end{array}$} & Control & 52.67 & 48.00 & 45.00 & 47.83 & 44.33 & 51.67 & $48.25^{\mathrm{f}}$ & \multirow{2}{*}{0.622} & \multirow{2}{*}{0.001} \\
\hline & Treatment & 40.83 & 41.67 & 48.67 & 40.83 & 40.17 & 42.83 & $42.50^{\mathrm{e}}$ & & \\
\hline \multirow{2}{*}{$\begin{array}{l}\text { Pulse rate/ } \\
\text { minute }\end{array}$} & Control & 54.00 & 51.67 & 54.33 & 56.83 & 58.17 & 55.83 & $55.14^{\mathrm{f}}$ & \multirow{2}{*}{0.676} & \multirow{2}{*}{0.001} \\
\hline & Treatment & 51.67 & 46.17 & 48.67 & 49.83 & 49.00 & 48.67 & $49.00^{\mathrm{e}}$ & & \\
\hline \multirow{2}{*}{$\begin{array}{l}\text { Forehead } \\
\text { temperature } \\
\left({ }^{\circ} \mathrm{C}\right)\end{array}$} & Control & 96.28 & 96.10 & 96.68 & 99.15 & 97.91 & 99.07 & 97.53 & \multirow[b]{2}{*}{0.113} & \multirow[b]{2}{*}{0.089} \\
\hline & Treatment & 95.28 & 94.93 & 95.79 & 98.83 & 96.91 & 98.86 & 96.77 & & \\
\hline \multirow{2}{*}{$\begin{array}{l}\text { Middorsal } \\
\text { temperature } \\
\left({ }^{\circ} \mathrm{C}\right)\end{array}$} & Control & 36.22 & 35.87 & 36.90 & 37.66 & 37.51 & 37.46 & $36.94^{\mathrm{d}}$ & \multirow[b]{2}{*}{0.057} & \multirow{2}{*}{0.002} \\
\hline & Treatment & 36.06 & 35.44 & 36.30 & 36.59 & 37.12 & 37.21 & $36.45^{\mathrm{c}}$ & & \\
\hline \multirow{2}{*}{$\begin{array}{l}\text { Thigh } \\
\text { temperature } \\
\left({ }^{\circ} \mathrm{C}\right)\end{array}$} & Control & 35.58 & 35.30 & 35.71 & 37.36 & 37.44 & 37.84 & $36.54^{b}$ & \multirow{2}{*}{0.091} & \multirow{2}{*}{0.047} \\
\hline & Treatment & 35.20 & 35.02 & 36.25 & 36.15 & 36.59 & 37.37 & $36.10^{\mathrm{a}}$ & & \\
\hline
\end{tabular}

Values with different superscript in a column differ significantly, i.e., $(\mathrm{a}, \mathrm{b})(P<0.05)$, $(\mathrm{c}, \mathrm{d})(P<0.01),(\mathrm{e}, \mathrm{f})$ $(\mathrm{P}<0.001)$ 
N. Haque et al.: Improved milk yield by modifying the micro-environment in Murrah buffaloes

Table 3. Effect of mist and fan cooling system on feed intake, milk yield and compositions of lactating Murrah buffaloes $(\mathrm{n}=12)$

\begin{tabular}{|c|c|c|c|c|c|c|c|c|c|c|}
\hline \multirow[b]{2}{*}{ Parameters } & \multirow[b]{2}{*}{ Group } & \multicolumn{6}{|c|}{ Week } & \multirow{2}{*}{$\begin{array}{c}\text { Overall } \\
\text { mean }\end{array}$} & \multirow{2}{*}{ SEM } & \multirow{2}{*}{$\begin{array}{l}\text { Significance } \\
\text { of effect }(\mathrm{P})\end{array}$} \\
\hline & & $1^{\text {st }}$ & $2^{\text {nd }}$ & $3^{\text {rd }}$ & $4^{\text {th }}$ & $5^{\text {th }}$ & $6^{\text {th }}$ & & & \\
\hline \multirow{2}{*}{ DMI } & Control & 14.93 & 14.51 & 14.89 & \begin{tabular}{|l|}
14.79 \\
\end{tabular} & 14.95 & 14.74 & 14.80 & \multirow{2}{*}{0.228} & \multirow{2}{*}{0.794} \\
\hline & Treatment & 14.88 & 15.16 & 15.02 & 14.90 & 14.64 & 14.96 & 14.92 & & \\
\hline \multirow{2}{*}{$\begin{array}{l}\text { Milk yield } \\
(\mathrm{kg})\end{array}$} & Control & 4.01 & 4.73 & 5.02 & 5.31 & 5.83 & 5.97 & $5.15^{\mathrm{a}}$ & \multirow{2}{*}{0.006} & \multirow{2}{*}{0.048} \\
\hline & Treatment & 4.17 & 4.85 & 5.69 & 6.27 & 7.13 & 7.30 & $5.90^{\mathrm{b}}$ & & \\
\hline \multirow{2}{*}{$\begin{array}{l}\text { Milk fat } \\
(\%)\end{array}$} & Control & 8.42 & 8.50 & 8.35 & 8.49 & 8.30 & 8.45 & 8.42 & \multirow{2}{*}{0.280} & \multirow{2}{*}{0.801} \\
\hline & Treatment & 8.65 & 8.62 & 8.43 & 8.58 & 8.61 & 8.50 & 8.56 & & \\
\hline \multirow{2}{*}{$\begin{array}{l}\text { Milk protein } \\
(\%)\end{array}$} & Control & 3.92 & 3.94 & 4.03 & 3.97 & 3.99 & 4.06 & 3.98 & \multirow{2}{*}{0.047} & \multirow{2}{*}{0.270} \\
\hline & Treatment & 4.07 & 4.08 & 4.10 & 4.04 & 4.08 & 4.17 & 4.09 & & \\
\hline \multirow{2}{*}{ Lactose (\%) } & Control & 4.82 & 4.87 & 4.90 & 4.92 & 4.91 & 4.84 & 4.88 & \multirow{2}{*}{0.022} & \multirow{2}{*}{0.180} \\
\hline & Treatment & 4.91 & 4.89 & 4.90 & 4.98 & 5.03 & 4.92 & 4.94 & & \\
\hline \multirow{2}{*}{$\begin{array}{l}\text { Milk SNF } \\
(\%)\end{array}$} & Control & 10.03 & 9.95 & 9.96 & 9.95 & 9.94 & 9.90 & 9.96 & \multirow{2}{*}{0.057} & \multirow{2}{*}{0.523} \\
\hline & Treatment & 9.99 & 9.93 & 10.02 & 10.06 & 10.11 & 10.10 & 10.03 & & \\
\hline \multirow{2}{*}{$\begin{array}{l}\text { Plasminogen } \\
(\mu \mathrm{g} / \mathrm{mL})\end{array}$} & Control & 8.38 & 5.80 & 5.73 & 6.83 & 6.81 & 7.38 & $6.82^{\mathrm{a}}$ & \multirow{2}{*}{0.279} & \multirow{2}{*}{0.037} \\
\hline & Treatment & 9.58 & 7.62 & 7.56 & 8.39 & 9.03 & 8.08 & $8.38^{\mathrm{b}}$ & & \\
\hline \multirow{2}{*}{$\begin{array}{l}\text { Plasmin }(\mu \mathrm{g} / \\
\mathrm{mL})\end{array}$} & Control & 0.190 & 0.196 & 0.243 & 0.214 & 0.247 & 0.267 & $0.226^{\mathrm{b}}$ & \multirow{2}{*}{0.002} & \multirow{2}{*}{0.042} \\
\hline & Treatment & 0.180 & 0.177 & 0.232 & 0.207 & 0.237 & 0.246 & $0.213^{\mathrm{a}}$ & & \\
\hline \multirow{2}{*}{$\begin{array}{l}\beta \text {-casein } \\
(\mathrm{g} / 100 \mathrm{~mL})\end{array}$} & Control & 1.05 & 1.02 & 0.99 & 0.96 & 1.08 & 0.99 & $1.02^{\mathrm{a}}$ & \multirow{2}{*}{0.018} & \multirow{2}{*}{0.045} \\
\hline & Treatment & 1.11 & 1.14 & 1.05 & 1.18 & 1.12 & 1.07 & $1.11^{\mathrm{b}}$ & & \\
\hline Calcium & Control & 193.85 & 191.23 & 189.33 & 197.21 & 190.75 & 193.11 & 192.58 & -4061 & 0.403 \\
\hline$(\mathrm{mg} / \mathrm{dL})$ & Treatment & 190.52 & 198.46 & 197.95 & 206.47 & 196.32 & 208.29 & 199.67 & & \\
\hline
\end{tabular}

Values with different superscript in a column differ significantly, i.e., $(a, b)(P<0.05)$; SNF $=$ solids not fat

The concentration of cortisol indicates a higher level of stress in buffaloes in the control group and it increased by $10.06 \%(\mathrm{P}<0.01)$ during the $\mathrm{HH}$ season (Table 4). There was no cooling effect on plasma catecholamine levels during the $\mathrm{HH}$ season. However, significantly higher plasma $\mathrm{GH}(\mathrm{P}<0.05)$ and glucose $(\mathrm{P}<0.001)$ and lower NEFA levels, by $11.26 \%(\mathrm{P}<0.001)$, were recorded in the treatment group animals (Table 4$)$. 
N. Haque et al.: Improved milk yield by modifying the micro-environment in Murrah buffaloes

Table 4. Effect of mist and fan cooling system on plasma hormones and metabolites of lactating Murrah buffaloes $(\mathrm{n}=12)$

\begin{tabular}{|c|c|c|c|c|c|c|c|c|c|c|}
\hline \multirow[b]{2}{*}{ Parameters } & \multirow[b]{2}{*}{ Group } & \multicolumn{6}{|c|}{ Week } & \multirow{2}{*}{$\begin{array}{c}\text { Overall } \\
\text { mean }\end{array}$} & \multirow[b]{2}{*}{ SEM } & \multirow{2}{*}{$\begin{array}{l}\text { Significance } \\
\text { of effect (P) }\end{array}$} \\
\hline & & $1^{\mathrm{st}}$ & $2^{\text {nd }}$ & $3^{\text {rd }}$ & $4^{\text {th }}$ & $5^{\text {th }}$ & $6^{\text {th }}$ & & & \\
\hline \multirow{2}{*}{$\begin{array}{l}\text { Cortisol } \\
(\mathrm{ng} / \mathrm{mL})\end{array}$} & Control & 12.99 & 12.07 & 11.54 & 11.97 & 12.81 & 10.82 & $12.03^{\mathrm{d}}$ & 0.190 & 0.009 \\
\hline & Treatment & 12.18 & 11.30 & 9.94 & 11.17 & 10.10 & 10.22 & $10.82^{\mathrm{c}}$ & & \\
\hline \multirow{2}{*}{$\begin{array}{l}\text { Growth } \\
\text { hormone } \\
(\mathrm{ng} / \mathrm{mL})\end{array}$} & Control & 4.21 & 4.03 & 4.91 & 4.35 & 4.90 & 5.16 & $4.59^{\mathrm{a}}$ & 0.131 & 0.029 \\
\hline & Treatment & 4.20 & 4.86 & 5.53 & 5.06 & 5.58 & 6.32 & $5.26^{\mathrm{b}}$ & & \\
\hline \multirow{2}{*}{$\begin{array}{l}\text { Epinephrine } \\
(\mathrm{ng} / \mathrm{mL})\end{array}$} & Control & 0.22 & 0.22 & 0.18 & 0.14 & 0.17 & 0.18 & 0.18 & 0.006 & 0.213 \\
\hline & Treatment & 0.20 & 0.18 & 0.16 & 0.15 & 0.16 & 0.15 & 0.17 & & \\
\hline \multirow{2}{*}{$\begin{array}{l}\text { Norepinephrine } \\
(\mathrm{ng} / \mathrm{mL})\end{array}$} & Control & 0.34 & 0.37 & 0.38 & 0.38 & 0.34 & 0.28 & 0.35 & 0.010 & 0.063 \\
\hline & Treatment & 0.32 & 0.33 & 0.36 & 0.35 & 0.29 & 0.23 & 0.31 & & \\
\hline \multirow{2}{*}{$\begin{array}{l}\text { Glucose } \\
\text { (mg/dL) }\end{array}$} & Control & 45.71 & 44.85 & 48.05 & 47.24 & 47.93 & 51.10 & $47.48^{\mathrm{e}}$ & 0.684 & 0.001 \\
\hline & Treatment & 49.92 & 47.48 & 53.37 & 57.99 & $54.80^{\mathrm{a}}$ & 57.16 & $53.45^{\mathrm{f}}$ & & \\
\hline \multirow{2}{*}{$\begin{array}{l}\text { NEFA } \\
(\mu \mathrm{mol} / \mathrm{L})\end{array}$} & Control & 501.27 & 478.91 & 494.23 & 481.16 & 485.67 & 476.00 & $486.21^{\mathrm{f}}$ & 3.879 & $<0.001$ \\
\hline & Treatment & 455.62 & 459.05 & 434.50 & 420.97 & 408.47 & 410.07 & $431.45^{\mathrm{e}}$ & & \\
\hline
\end{tabular}

Values with different superscript in a column differ significantly, i.e., (a, b) $(\mathrm{P}<0.05)$, (c, d) $(\mathrm{P}<0.01),(e, f)$ $(\mathrm{P}<0.001)$; NEFA $=$ Non-esterified fatty acid

\section{Discussion}

Rectal temperature is considered to be a good measure of core body temperature and may be used as an indicator of thermal balance, to assess the adversity of the thermal environment and detect the response of animals to environmental conditions. However, the non-significant variation in RT in our present investigation may indicate a comparable inherent body temperature in both the treatment and control groups of animals. Nevertheless, the cooling system was found to be beneficial to provide comfort to the animals by significantly reducing the skin temperature in different regions, which is also supported by previous studies (AGGARWAL and SINGH, 2008; HAQUE et al., 2012b). The results of RR are in agreement with the observations of HAQUE et al. (2012a); and SINGH et al. (2014). The increase in RR in the control animals with the increasing temperature may be due to the greater demand for oxygen by the tissues in stressful conditions and the attempt to increase heat loss by evaporative cooling (AGGARWAL and SINGH, 2006). Provision of a cooling system during the summer significantly affected the RR, implying that RR plays an important role in the thermoregulatory mechanism in relation to all the physiological reactions and body temperature. The effect of the cooling system during the summer was also found to be beneficial in maintaining pulse rate in the $\mathrm{HH}$ season (SINGH et al., 2014). It has been found that an increase in pulse rate increases 
N. Haque et al.: Improved milk yield by modifying the micro-environment in Murrah buffaloes

blood flow from the core to the surface as a result of which more heat is lost by sensible (loss by conduction, convention and radiation) and insensible (loss of water by diffusion from the skin) means (MARAI et al., 2007).

The present findings of a decline in MY during heat stress are in agreement with previous findings in cows (RHOADS et al., 2009). When cows are subjected to heat stress, feed intake decreases. Simultaneously, maintenance requirements are increased due to activation of the thermoregulatory system. There is a need to expend energy that would otherwise be available for useful production, to maintain homeothermy. However, provision of mist and fan cooling was found to be beneficial during heat stress to restore thsi capability, and resulted in increased milk yield. A non-significant variation in milk composition was recorded in our present investigation, which is supported by NAIK et al. (2014), who also reported no adverse effects of high ambient temperature on milk composition. However, variations in milk constituents due to heat stress were reported by several researchers (BAHASHWAN, 2014).

The higher level of plasminogen in the treatment group during the $\mathrm{HH}$ season indicated lower conversion of inactive plasminogen compound to active plasmin enzymes. It is well-documented that plasminogen conversion to plasmin is related to stressful conditions in lactating animals, which ultimately helps to reduce the lactation energy burden by reducing milk yield (HAQUE et al., 2015). Hence it may be concluded that the cooling system in the summer was effective in minimizing environmental stress in the buffaloes. Similarly, the higher levels of plasmin in the control group in the experimental season was attributed to environmental stress induced by higher conversion of plasminogen to plasmin. Milk $\beta$-casein levels were higher $(\mathrm{P}<0.05)$ in the treatment group as compared to the control group in the $\mathrm{HH}$ season. This may indicate that there was less degradation of $\beta$-casein to $\beta$-casein fragment ( $\beta \mathrm{CN} \mathrm{f} \mathrm{1-28)} \mathrm{in} \mathrm{the} \mathrm{treatment} \mathrm{group.} \mathrm{Thus,} \mathrm{the} \mathrm{use} \mathrm{of}$ mist and fan cooling during the summer had a beneficial effect on the animals against seasonal stress and was found to be effective in improving milk production potential through manipulation of the PG-PL system. Several authors have shown that seasonal temperature has no effect on calcium concentrations (McADAM and O'DELL, 1982), which is confirmed by our present study. However, SEVI et al. (2001) found a marked reduction in plasma Ca levels in ewes exposed to high ambient temperature, and suggested that the parathyroid hormone may be involved in this mechanism.

Plasma cortisol concentrations have been used as physiological markers of stress (MEGAHED et al., 2008) in both cattle (CHAIYABUTR et al., 2008) and swamp buffalo (HAQUE et al., 2012a). However, the modified management practices in our present experiment were shown to improve the status of cortisol levels. Previously, it was also shown that animals provided with access to a wallow exhibit significantly $(\mathrm{P}<0.05)$ lower cortisol levels than the cortisol levels of animals in the control group (KHONGDEE 
N. Haque et al.: Improved milk yield by modifying the micro-environment in Murrah buffaloes

et al., 2011). The cortisol levels of buffalo with access to a wallow were also reported to be lower (AGGARWAL and SINGH, 2010). Similar effects were also reported by VIJAYAKUMAR et al. (2011). Therefore, it may be concluded that provision of mist and fan during the summer provided comfort, and changed the micro-environment of the buffalo, which was evident in the blood cortisol levels.

The reports on the effect of high temperatures on GH level are highly variable. The reduction in plasma GH level in the control group animals during the hot humid season could be due to higher release of corticotrophin-releasing hormone (CRH). CRH stimulates somatostatin release from the hypothalamus, which can inhibit secretion of somatotropin and thyroid stimulating hormones from the pituitary, and down-regulate the thermogenic effects of both somatotropin and thyroid hormones (COLLIER et al., 2006). ANAND and PRAKASH (2008) also found that plasma GH concentrations and secretion rates declined in hot temperatures $\left(35^{\circ} \mathrm{C}\right)$. Catecholamines (epinephrine and norepinephrine) and their metabolites are used for evaluation of several types of behaviors, neuro-endocrine disorders and physiological and pathological stress situations, as neurotransmitters or as hormones (CONNOLLY et al., 1991), and their concentrations in cattle used to be measured during heat exposure. However, the non-significant effect on catecholamine levels in our present study may be the result of acclimatization to the climatic conditions to which the buffaloes were exposed and the thermogenic effect of the hormones which prevented further increase in hormone levels in the control group of animals.

The level of blood glucose depends on the nutritive value of the diet, social or environmental stress, and the physiological status of the animal (BORGHESE, 2005). The decrease in blood glucose levels in the control group animals found in the present investigation was probably due to high glucose utilization during the hot humid season, since there was lower quality forage to provide energy. SINGH et al. (2014) also reported that plasma glucose levels decreased by $15.69 \%$, with an increase in THI score from 72 to 84 in lactating cows. However, SILANIKOVE (2000) reported significant increases in plasma glucose concentrations during acute heat stress exposure. The concentration of NEFA in the blood reflects the degree of adipose tissue mobilization, therefore, the greater the extent of negative energy balance, the more NEFA are released from body fat, and the higher the concentration of NEFA in the blood. Marked alterations in both carbohydrate and lipid metabolism ensure the partitioning of dietary-derived and tissue-originating nutrients toward the mammary glands. Although energy balance is the main determinant of plasma NEFA concentration, other factors also have an important influence on plasma NEFA concentration (impending parturition, stress, previous nutritional history, etc.). In our present study, higher NEFA levels indicate a higher degree of lipolysis in the control group as compared to the treatment group, to maintain energy supply due to climatic stress (extreme high temperatures and humidity during the $\mathrm{HH}$ season). 
N. Haque et al.: Improved milk yield by modifying the micro-environment in Murrah buffaloes

\section{Conclusion}

This experiment confirmed the negative effect of heat stress on the buffaloes as highlighted by down regulation in milk production performance in the control group through activation of the endogenous PG-PL system. Along with this, misting and fan cooling proved to be highly effective as a cooling strategy during the hot and humid period by preventing alterations in the physio-biochemical and endocrine response, However, knowledge of animal responses to heat stress during the hot months, as well as during extreme heat events, requires further investigation and elucidation of the mechanisms may facilitate the adoption of comprehensive preventive and control measures to combat heat stress in domestic animals.

\section{Acknowledgements}

The authors are thankful to the Director of the National Dairy Research Institute, Karnal Haryana, for providing the necessary facilities to carry out this experiment, and also to the Board of Research of the Nuclear Science / Bhaba Atomic Research Centre, (BRNS/BARC) Mumbai, India for providing the necessary funds in the project No.2013/35/48/BRNS to carry out this investigation.

\section{Conflicts of interest}

The authors declare that they have no conflict of interest.

\section{References}

AGGARWAL, A., M. SINGH (2006): Effect of water cooling on physiological responses, milk production and composition of Murrah buffaloes during hot-humid season Indian J. Dairy Sci. 59, 386-389.

AGGARWAL, A., M. SINGH (2008): Skin and rectal temperature changes in lactating buffaloes provided with showers and wallowing during hot-dry season. Trop. Anim. Health. Prod. 40, 223-228.

AGGARWAL, A., M. SINGH (2010): Hormonal changes in heat-stressed Murrah buffaloes under two different cooling systems. Buffalo Bull. 29, 1-6.

ANAND, L. N., B. S. PRAKASH (2008): Comparative profiles of different lipoprotein cholesterol parameters and growth hormone during hot humid and winter season in Murrah Buffaloes Livest. Sci. 115, 294-300.

BAHASHWAN, S. (2014): Effect of cold and hot seasons on fat, protein and lactose of Dhofari cow's milk. Net J. Agric. Sci. 2, 47-49.

BAHFS (2014). Basic Animal Husbandry and Fisheries Statistics (http://dahd.nic.in/dahd/statistics/ animalhusbandry-statistics-division.aspx)

BORGHESE, A. (2005): Metabolic and hormonal parameters in buffaloes in Buffalo production and research. REU Technical Series 67. Inter-regional Cooperative Research Network on 
N. Haque et al.: Improved milk yield by modifying the micro-environment in Murrah buffaloes

Buffalo. (Borghese, A., Ed.). Food and Agriculture Organization of the United Nations (FAO), Rome. pp. 220.

BROWN-BRANDL, T. M., J. A. NIENABER, R. A. EIGENBERG, G. L. HAHN, H. C. FREETLY (2003): Thermoregulatory responses of feeder cattle. J. Therm. Biol. 28, 149-157.

BURGOS, R., L. J. ODENS, R. J. COLLIER, L. H. BAUMGARD, M. J. VANBAALE (2007): Evaluation of different cooling systems in lactating heat stressed dairy cows in a semi-arid environment. Prof. Anim. Scient. 23, 546-555.

CHAIYABUTR, N., S. CHANPONGSANG, S. SUADSONG (2008): Effects of evaporative cooling on the regulation of body water and milk production in crossbred Holstein cattle in a tropical environment. Int. J. Biometeorol. 52, 575-585.

COLLIER, R. J., G. E. DAHL, M. J. VANBAALE (2006): Major advances associated with environmental effects on dairy cattle. J. Dairy Sci. 89, 1244-1253.

CONNOLLy, C. C., K. E. STEINER, R. W. STEVENSON, D. W. NEAL, P. E. WILLIAMS, K. G. M. M. ALBERTI, A. D. CHERRINGTON (1991): Regulation of glucose metabolism by norepinephrine in conscious dogs. Am. J. Physiol. 261, E764-E772.

HAQUE, N., A. LUDRI, S. A. HOSSAIN, M. ASHUTOSH (2012a): Alteration of metabolic profiles in young and adult Murrah buffaloes exposed to acute heat stress. Int. J. Appl. Anim. Sci. 1, 23-29.

HAQUE, N., A. LUDRI, S. A. HOSSAIN, M. ASHUTOSH (2012b): Comparative studies on temperature threshold for heat shock protein 70 induction in young and adult Murrah buffaloes. J. Anim. Physiol. Anim. Nutr. 96, 920-929.

HAQUE, N., M. SINGH, S. A. HOSSAIN (2015): PA-PG-PL system in dairy animals and its significance: a review. Int. J. Dairy Sci.10, 95-106.

JOHNSON, H. D., A. C. RAGSDALE, I. L. BERRY, M. D. SHANKLIN (1963): Temperaturehumidity effects including influence of acclimation in feed and water consumption of Holstein cattle. Missouri Agr. Exp. Sta. Res. Bul. 846.

KEARL, L. C. (1982): Nutrient requirements of ruminants in developing countries. International Feedstuffs Institute, Utah Agricultural Experiment Station, Utah State University, Logan, UT, USA.

KHONGDEE, T., S. SRIPOON, C. VAJRABUKKA (2011): The effects of high temperature and wallow on physiological responses of swamp buffaloes (Bubalus bubalis) during winter season in Thailand. J. Therm. Biol. 36, 417-421.

MARAI, I. F. M., A. A. EL DARAWANY, A. FADIEL, M. A. M. ABDEL HAFEZ (2007): Physiological traits as affected by heat stress in sheep a review. Small Ruminant Res. 71, 1-12.

McADAM, P. A., G. D. O'DELL (1982): Mineral profile of blood plasma of lactating dairy cows. J. Dairy Sci. 65, 1219-1226.

McDOWELL, R. E., N. W. HOOVEN, J. K. CAMOENS (1976): Effects of climate on performance of Holsteins in first lactation. J. Dairy Sci. 59, 965-973. 
N. Haque et al.: Improved milk yield by modifying the micro-environment in Murrah buffaloes

MEGAHED, G. A., M. M. ANWAR, S. I. WASFY, M. E. HAMMADEH (2008): Influence of heat stress on the cortisol and oxidant-antioxident balance during oestrous phase in buffalo-cows (Bubalus bubalis): Thermo-protective role of antioxidant treatment. Reprod. Domest. Anim. 43, 672-677.

NAIK, S. V., M. SINGH, H. D. SHARMA (2014): Short term changes in plasma hormones, metabolites, milk yield and physiological responses in epinephrine administrated cows. J. Bio. Innov. 3, 63-72.

NAZIFI, S., H. GHEISARI, H. POORABBAS (1999): The influence of thermal stress on serum biochemical parameters of dromedary camels and their correlation with thyroid activity. Comp. Heamatol. Int. 9, 49-53.

RHOADS, M. L., R. P. RHOADS, J. J. VANBAALE, R. J. COLLIER, S. R. SANDERS, W. J. WEBER, B. A.CROOKER, L. H. BAUMGARD (2009): Effects of heat stress and plane of nutrition on lactating Holstein cows: I. Production, metabolism, and aspects of circulating somatropin. J. Dairy Sci. 92, 1986-1997.

SEVI, A., G. ANNICCHIARICO, M. ALBENZIO, L. TAIBI, A. MUSCIO, S. DELL'AQUILA (2001): Effect of solar radiation and feeding time on behavior, immune responses and production of lactating ewes under high ambient temperature. J. Dairy Sci. 84, 629-640.

SHEBAITA, M. K., I. M. EL-BANNA (1982): Heat load and heat dissipation in sheep and goats under environmental heat stress. In: Proc. $6^{\text {th }}$ Int. Conf. on Animal and Poultry Production, held at University of Zagazig, Zagazig, Egypt, 21-23 September 1982, Vol. 2. Egyptian Society of Animal Production, 459-469.

SHIPE, W. F., G. F. SENYK, K. B. FOUNTAIN (1980): Modified copper soap solvent extraction method for measuring free fatty acids in milk. J. Dairy Sci. 63, 193-198.

SILANIKOVE, N. (2000): The physiological basis of adaptation in goats to harsh environments. Small Ruminant Res. 35, 181-193.

SILANIKOVE, N., F. SHAPIRO, D. SHINDER (2009): Acute heat stress brings down milk secretion in dairy cows by up-regulating the activity of the milk-borne negative feedback regulatory system. BMC Physiol. 9, 13.

SINGH, A. K., R. DEVI, Y. KUMAR, P. KUMAR, R. C. UPADHYAY (2014): Physiological changes and blood flow in Murrah buffaloes during summer and winter season. J. Buffalo Sci. 3, 63-69.

VIJAYAKUMAR, P., T. DUTT, M. SINGH, H. N. PANDEY (2011): Effect of heat ameliorative measures on the biochemical and hormonal responses of buffalo heifers. J. Appl. Anim. Res. $39,181-184$.

Received: 13 January 2017

Accepted: 30 May 2017 


\section{HAQUE, N., M. SINGH, S. A. HOSSAIN: Utjecaj promijenjenog mikrookoliša na pojavu stresa i proizvodnju mlijeka putem sustava plazminogen - plazmin u Murrah-bivola tijekom vruće i vlažne sezone. Vet. arhiv 88, 201-213, 2018. \\ SAŽETAK}

S ciljem određivanja promjena u proizvodnji i sastavu mlijeka te plazminogen-plazminskog sustava (PGPL) mlijeka, analizirani su hormoni plazme i metaboliti tijekom vruće i vlažne sezone. Bivoli su podijeljeni u dvije skupine: pokusnu i kontrolnu. Životinje u pokusnoj skupini izvrgnute su utjecaju magle i ventilatora za hlađenje svaki dan od 9,30 do 17,00 sati tijekom 6 tjedana. Kod životinja u kontrolnoj skupini navedeni postupak nije primijenjen. Prosječna maksimalna temperatura tijekom promatrane sezone iznosila je $34,33{ }^{\circ} \mathrm{C}$ a temperaturno-vlažni indeks 84,18. Tijekom 6 tjedana, u tjednim intervalima, kod životinja su registrirani fiziološki pokazatelji te prikupljani uzorci mlijeka i krvi. Bivoli u pokusnoj skupini bili su izloženi boljoj udobnosti zbog koje su njihovi fiziološki pokazatelji, brzina disanja, brzina bila i temperature kože, bili značajno smanjeni $(\mathrm{P}<0,05)$ u usporedbi s bivolima u kontrolnoj skupini, što je rezultiralo i povećanjem prinosa mlijeka za $14,56 \%$. Usporedna analiza uzoraka mlijeka između dviju skupina bivola pokazala je u pokusnoj skupini veću koncentraciju plazminogena (pokusna skupina 8,38 u odnosu na $6,82 \mu \mathrm{g} / \mathrm{mL}$ kontrolne skupine) i $\beta$-kazeina (pokusna skupina $1,11 \mathrm{u}$ odnosu na $1,02 \mathrm{~g} / \mathrm{dL}$ kontrolne skupine) te nižu razinu plazmina (pokusna skupina $0,213 \mathrm{u}$ odnosu na $0,226 \mu \mathrm{g} / \mathrm{mL}$ kontrolne skupine). Razina hormona rasta u plazmi i razina glukoze bile su veće, dok su razine kortizola i neesterificiranih masnih kiselina bile niže $(\mathrm{P}<0,05)$ kod životinja pokusne skupine. No, izlaganje bivola rashladnom sustavu nije promijenilo sastav mlijeka, sadržaj kalcija u mlijeku kao ni razine katekolamina u plazmi. Stoga se može zaključiti da je primjena sustava hlađenja tijekom ljeta za bivole bila učinkovita zbog smanjivanja utjecaja stresa iz okoliša te poboljšanja proizvodnje mlijeka manipulacijom PG-PL sustava.

Ključne riječi: Murrah-bivol; vruća i vlažna sezona; magla i ventilator; plazminogen-plazmin; metaboliti krvi; toplinski stres 
